\title{
Narrative Review: NANO KAPSUL EKSTRAK BIJ PAPAYA (Carica Papaya L.) SEBAGAI ANTIFERTILITAS
}

\author{
Narrative Review: Nano Capsules Papaya Seed Extract (Carica Papaya L.) As \\ Antifertility
}

\author{
Shinta Nur Fajriyah ${ }^{*}$ \\ Yuliana Eka Lestari ${ }^{2}$ \\ Nadiatul Istiqamah Suaka ${ }^{3}$ \\ Endang Darmawan ${ }^{4}$
}

*IFakultas Farmasi, Universitas Ahmad Dahlan, Kota Yogyakarta, Daerah Istimewa Yogyakarta, Indonesia

2Fakultas Farmasi, Universitas Ahmad Dahlan, Kota Yogyakarta, Daerah Istimewa Yogyakarta, Indonesia

3Fakultas Farmasi, Universitas Ahmad Dahlan, Kota Yogyakarta, Daerah Istimewa Yogyakarta, Indonesia

${ }^{4}$ Dosen Fakultas Farmasi, Universitas Ahmad Dahlan, Kota Yogyakarta, Daerah Istimewa Yogyakarta, Indonesia

*email:

Shintal700023004@webmail.uad.ac.id

Kata Kunci:
Ekstrak biji papaya
Nanokapsul
Antifertilitas

Keywords:
Papaya seed extract
Nano capsule
Antifertility

Antifertility

\begin{abstract}
Abstrak
Background. Pepaya merupakan tumbuhan yang banyak terdapat di Indonesia. Biji secara tradisional sudah digunakan untuk antifertilitas karena menarik untuk dimanfaatkan. Pada seluruh bagian tumbuhan dapat dimanfaatkan oleh manusia, baik dari buah, daun, biji, getah dan batangnya, ekstrak biji papaya mengandung senyawa metabolit sekunder golongan triterpenoid, flavonoid, alkaloid, saponin, dan tannin yang dapat berfungsi sebagai antifertilitas. Nanokapsul merupakan suatu inovasi dari sediaan nanopartikel, dengan ukuran partikel yang kecil sehingga dapat mempercepat obat menuju target. Narrative review ini bertujuan untuk mengetahui kegunaan nanokapsul ekstrak biji Carica papaya sebagai antifertilitas.

Metode. Penelitian ini merupakan narrative review. Sebanyak 36 artikel yang memenuhi kriteria inklusi dan eksklusi dianalisis secara deskriptif sebanyak 36 artikel meliputi dengan khasiat papaya, nanokapsul, dan antifertilitas. Artikel yang digunakan meliputi artikel yang di publish di jurnal nasional dan jurnal Internasional. Hasil narrative review disajikan dalam bentuk deskriptif. Hasil. Hasil penelusuran menunjukkan bahwa I) Carica papaya dapat dimanfaatkan secara tradisional untuk mengobati penyakit kulit, penyakit diare dan mengatasi gangguan pencernaan secara penelitian dapat digunakan sebagai antifertilitas, 2) Ukuran nanopartikel yang diperoleh pada penelitian antara 76,47nm hingga 693,8nm, dan 3) Ekstrak biji Carica papaya digunakan sebagai antifertilitas dengan menurunkan jumlah sperma, $\mathrm{pH}$ mani, proses spermatogenesis, menggaunggu aksi hipofisis gonad, secara preklinik menurunkan jumlah kualitas sel telur dan jumlah folikel de Graff pada mencit betina.
\end{abstract}

Kesimpulan. Secara keseluruhan dapat disimpulkan bahwa Carica papaya dengan nanokapsul ukuran partikel antara 76,47 nm hingga 693,8 nm bisa digunakan sebagai antifertilitas secara preklinik dapat mempengaruhi fungsi reproduksi mencit betina dan jantan.

\section{Abstract}

Background. Papaya (Carica Papaya. $L$ ) is a plant that commonly found in Indonesia. Interestingly, its seeds traditionaly used as antifertility. All parts of Carica Papaya. $L$ tree can be used for human needs from the fruit, leaves, seeds, sap, and stems. Carica Papaya. $L$ seed extract contains secondary metabolite compounds in class Triterpenoids, flavonoids, alkaloids, saponins, and tannins which have functioned as antifertility. Nanocapsule is an innovation of nanoparticle dosage form with small particle size, that can accelerate the drug to the target. This Narrative Review purposed to determine the usefulness of the nanocpsules of Carica Papaya. $L$ seed extract as antifertility.

Method. This research is a Narrative Review. A total of 36 articles that met the inclusion and exclusion criteria were analyzed descriptively, which include efficacy of Papaya, nanocapsules and antifertilities. The articles used include articles published in national journals and international journals. The result of Narrative Review are presented in descriptive form.

Result. The results of research show that I) Carica Papaya. $L$ can be used traditionally to treat skin diseases, diarrheal desease, overcoming digestive disorders, and by research can be used as antifertility, 2) The size of the nanoparticles obtained in the study ranged from $76.47 \mathrm{~nm}$ to $693.8 \mathrm{~nm}$, and 3) Carica Papaya. $L$ seed extract is used as an antifertility by reducing sperm quantity, semen $\mathrm{pH}$, spermatogenesis process, interfering the action of pituitary gonads, by preclinical reducing the number of ovum quality and the number of de Graff Follicles in female mice.

Conclusion. Overall, it can be conclude that Carica Papaya. $L$ nanocapsules in particle sizes between $76.46 \mathrm{~nm}$ to $693.8 \mathrm{~nm}$ can be used as antifertility that preclinicaly can affect the reproduction of female and male mice. 

Shinta Nur Fajriyah,Yuliana Eka Lestari,Nadiatul Istiqamah Suaka, Endang Darmawan, 2021. Narrative Review: Nano Capsules Papaya Seed Extract (Carica Papaya L.) As Antifertility

\section{PENDAHULUAN}

\section{Pepaya}

Tanaman adalah sumber utama yang dapat digunakan sebagai obat baru, termasuk obat sebagai antifertilitas. Berbagai macam jenis tumbuhan yang ada di Indonesia dapat dijadikan bahan herbal untuk membuat obat antifertilitas. Obat herbal tersebut diharapkan aman jika dikonsumsi tanpa menimbulkan bahaya efek samping yang merugikan pada masyarakat.

Menurut Fauziyaha (2013) pepaya (Carica pepaya Linn.) terkenal karena kandungan nutrisi dan obatnya yang luar biasa di seluruh dunia. Seluruh tumbuhan termasuk daun, buah, biji, kulit kayu, getah dan sarinya digunakan sebagai obat. Pepaya dianggap sebagai buah nutracuitical duo khasiatnya yang multifaset. Seluruh tanaman pepaya mengandung enzim papain, likopen, isothyocynate, mineral penting, vitamin, arbohidrat, kakrotenoid dan flavonoid.

Pavithra (2017) menyatakan bahwa banyak khasiat yang diperoleh dari papaya baik dari buah, daun, biji atau pun lainnya. Kulit papaya dapat menjadi nutrisi kulit, komposisi kulit pepaya menunjukkan bahwa kulit pepaya merupakan sumber protein, serat, mineral dan kandungan $\beta$-karoten yang baik. Selain itu ekstrak biji dan daun Carica Pepaya dapat digunakan sebagai antibakeri dan efektif melawan E. coli, Salmonella dan infeksi Staphylococcus (Peter, 2014). Menurut penelitian Charan (2016) ekstrak daun pepaya memiliki peran yang pasti dalam meningkatkan jumlah trombosit pada pasien DBD, karena ada efek positif yang signifikan secara statistic terhadap peningkatan jumlah trombosit.

\section{Nanokapsul}

Berdasarkan penelitian Satriyas (2018) Nanokapsul merupakan sediaan nanopartikel dalam bentuk sediaan kapsul. Nanopartikel merupakan suatu partikel koloid ataupun padatan dengan diameter antara 100-1000nm. Rachmawati (2017) mengatakan dalam bidang farmasi, terdapat dua pengertian nanopartikel yaitu senyawa obat melalui suatu cara dibuat berukuran nanometer (nanokristal) dan suatu obat dienkapsulasi dalam suatu sistem pembawa berukuran nanometer, yaitu nanocarrier. Dalam sistem penghantar obat, nanopartikel berperan sebagai pembawa dengan cara melarutkan, menjebak, mengenkapulasi obat di dalam matriksnya atau pembawanya (Julianawati, et al., 2020). Menurut Napsah (2014) Nanopartikel menggunakan polimer dapat dimanfaatkan untuk sistem penghantaran tertarget, meningkatkan bioavailabilitas, pelepasan obat terkendali, atau melarutkan obat untuk penghantaran sistemik. Tujuan pembuatan nanopartikel yaitu untuk meningkatkan stabilitas senyawa aktif terhadap degradasi lingkungan (oksidasi, hidrolisis, dan penguraian enzimatis), memperbaiki sistem penghantaran obat melalui suatu rute tertentu, memperbaiki absorbsi senyawa seperti makromolekul, mempermudah penanganan bahan toksik, menutupi rasa dan bau yang kurang menyenangkan dari suatu zat aktif, mengurangi efek iritasi zat aktif terhadap saluran pencernaan, memodifikasi pelepasan zat aktif, dan meningkatkan kelarutannya dalam air (sitasi belum). Menurut Buzea, et al., dalam Martien R., et al., (20l2) beberapa kelebihan nanopartikel adalah kemampuan untuk menembus ruang-ruang antar sel yang hanya dapat ditembus oleh ukuran partikel koloidal kemampuan untuk menembus dinding sel yang lebih tinggi, baik melalui difusi maupun opsonifikasi, dan fleksibilitasnya untuk dikombinasi dengan berbagai teknologi lain sehingga membuka potensi yang luas untuk dikembangkan pada berbagai keperluan dan target. Sedangkan menurut Kawasima dalam Martien R., et al., (2012:134) kelebihan lain dari nanopartikel adalah adanya peningkatan afinitas dari sistem karena peningkatan luas permukaan kontak pada jumlah yang sama.

Kitosan merupakan polisakarida alam glukosamin (2asetamido-2-deoksi-d-glukoosa) $\mathrm{N}$-asetil glukosamin saat ini mulai banyak dimanfaatkan dalam bidang farmasi, kesehatan dan pangan. Kitosan bersifat anti mikroba,tidak beracun, wound healing, biokompatibel, biodegredabel, serta larut dalam air. Kitosan dalam 
bentuk nanopartikel memiliki keunggulan diantaranya tidak toksik, stabil selama penggunaan, luas permukaan yang tinggi, dapat diaplikasikan untuk berbagai jenis oba dan ekstrak tanaman (Dai, et al., 20II). Kitosan digunakan sebagai penyalut obat selain itu juga digunakan untuk menahan pelepasan obat di dalam tubuh (Julianawati, et al., 2020). Nanopartikel dengan bahan kitosan dapat dimanfaatkan dalam penghantar obat dengan target usus besar, penghantar obat pada selaput mukosa, terapi kanker, penghantar gen, penghantar topikal, penghantaran okular dan penghantaran lambung atau salutan pencernaan ( $\mathrm{Li}$, et al., 2018).

Teknik gelasi ionik adalah teknik utama untuk interaksi ionik menggunakan kitosan sebagai senyawa polikation. Pada teknik gelasi ionik, nanopartikel juga dibentuk oleh suatu senyawa polianion misalnya tripolifosfat. Metode dengan gelasi ionik dapat diinduksi dengan sistem dengan dua dispersi koloid dengan muatan yang berlawanan. Vaersic (2010) mengatakan bahwa netralisasi muatan positif oleh adanya muatan negative dapat menyebabkan pemisahan. Mekanisme nanopartikel kitosan berdasarkan interaksi elektrostatik antara gugus amina kitosan dengan gugus bermuatan negative dari polianon.

\section{Antifertilitas Biji Pepaya}

Keluarga berencana merupakan program yang dirancang untuk mengendalikan laju pertumbuhan penduduk secara luas di negara Indonesia. Untuk menghindari potensi dampak destruktif dari ledakan penduduk, Program Keluarga Berencana berskala nasional telah lama diadopsi di Indonesia. Agar berhasil, keluarga berencana harus melibatkan partisipasi laki-laki dan perempuan. Berdasarkan uraian tersebut (Carica papaya L.) dapat digunakan sebagai solusi untuk melakukan program KB dari ekstrak biji papaya yang merupakan KB alami.

Pada penelitian ini dibuat sediaan nano kapsul atau nanopartikel dengan kitosan-tpp dari ekstrak biji papaya sebagai anti fertilitas. Menurut Julianawati (2015) Nanopartikel adalah salah satu strategi untuk meningkatkan bioavailabilitas senyawa aktif herbal, sedangkan nano kapsul merupakan sediaan nanopartikel yang dikemas dalam sediaan kapsul. Kitosan adalah polikationik polimer non toksisk biodegradable dengan imunogenisitas rendah, yang telah diteliti untuk merumuskan system pembawa dan pengiriman untuk terapi makro (Gan, 2005). Kitosan terdiri dari $\beta$ - I,4terkait glukosamin dan $\mathrm{N}$ residu asetilglukosamin, baik derajat asetilasi (DA) dan derajat polimerisasi (DP) kitosan adalah faktor penting yang diketahui untuk mengatur sifat struktural dan fungsional (Sreekuma, 2018). Kitosan sebagai polimer hidrofilik dapat dengan mudah di-cross-link dengan counter poli anion seperti Na-TPP untuk mengontrol pelepasan obat (Kailakua, 2014).

Ekstrak etanol biji pepaya mentah (Carica papaya Linn.) dapat digunakan sebagai antifertilitas dengan hasil perbedaan yang signifikan pada parameter FSH dan $\mathrm{LH}$ antara kelompok kontrol dan intervensi. Pemberian ekstrak etanol biji pepaya mentah menurunkan angka rata-rata kadar FSH dan LH. Namun perlu dilakukan penelitian lebih lanjut tentang uji toksisitas ekstrak etanol biji pepaya muda. Jika kajian pada hewan cukup dan aman, maka perlu dilakukan penelitian lain pada manusia guna mencari alternatif baru kontrasepsi pria.

\section{METODOLOGI}

Penelitian ini merupakan penelitian narrative review yang mengidentifikasi, menilai, dan menginterpretasi seluruh temuan-temuan pada suatu topik penelitian, untuk menjawab pertanyaan penelitian yang telah ditetapkan sebelumnya (Kitchenham \& Charters, 2007). Artinya tidak hanya bermakna membaca literatur, tapi lebih ke arah evaluasi yang mendalam dan kritis tentang penelitian sebelumnya pada suatu topik penelitian, dan kemudian merangkumkan, menganalisis dan mensintesis isinya dan menyajikannya dalan bentuk suatu survey 
Shinta Nur Fajriyah,Yuliana Eka Lestari,Nadiatul Istiqamah Suaka, Endang Darmawan, 2021. Narrative Review: Nano Capsules Papaya Seed Extract (Carica Papaya L.) As Antifertility

paper dan melakukan evaluasi terhadap kualitas dan temuan baru dari suatu paper ilmiah.

Sampel pada penelitian ini adalah jurnal internasional dan jurnal nasional. Kriteria sampel meliputi kriteria inklusi dan kriteria eksklusi, dimana kriteria tersebut menentukan dapat atau tidaknya sampel digunakan. Kriteria inklusi antara lain; jurnal internasional dan nasional yang membahas khasiat papaya, nanopartikel, nanokapsul, antifertilitas, folikel de Graff dan jurnal dalam bentuk full text. Sedangkan kriteria eksklusi antara lain; jurnal internasional dan nasional yang tidak membahas kahsiat papaya, nanopartikal nanokapsul, antifertilitas, folikel de Graff dan jurnal tidak dalam bentuk full text.

\section{Skema Penelitian}

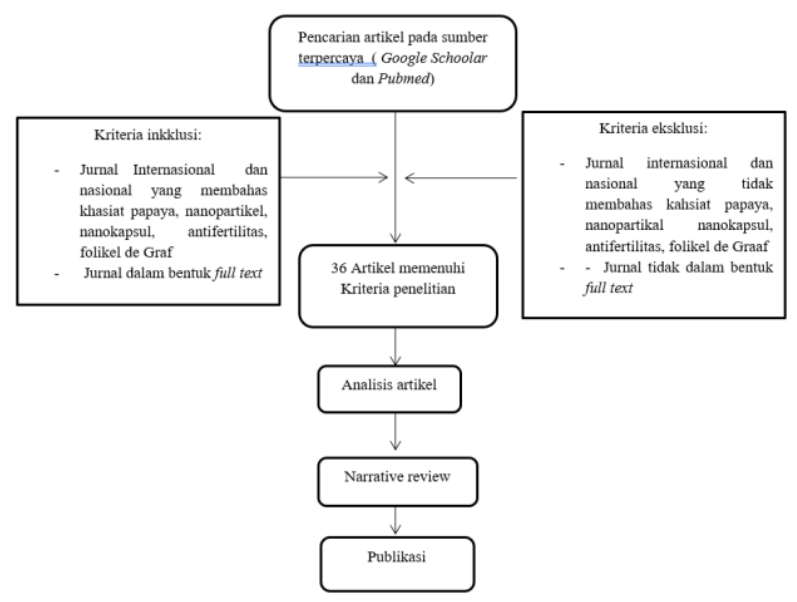

\section{Cara analisis data}

Hasil penelitian dianalsis secara diskriptif dan data dikompilasikan dari berbagai sumber yang didapatkan.

\section{HASIL DAN PEMBAHASAN}

\section{Hasil}

\section{Pepaya}

Tabel I. Perbandingan khasiat pepaya

\begin{tabular}{l|l|l}
\hline & $\begin{array}{l}\text { Bagian yang } \\
\text { Manfaatkan }\end{array}$ & Hasil \\
\hline
\end{tabular}

\begin{tabular}{|c|c|c|}
\hline $\begin{array}{l}\text { Udoh et } \\
\text { al (2005) }\end{array}$ & $\begin{array}{l}\text { Ekstrak biji } \\
\text { Carica papaya }\end{array}$ & $\begin{array}{l}\text { Ekstrak biji mencegah } \\
\text { pembuahan sel telur, } \\
\text { mengurangi jumlah sel } \\
\text { sperma, mengungkapkan } \\
\text { degenerasi sel sperma, } \\
\text { dan menyebabkan lesi sel } \\
\text { testis. }\end{array}$ \\
\hline $\begin{array}{l}\text { Otsuki et } \\
\text { al }(2011)\end{array}$ & $\begin{array}{l}\text { Ekstrak daun } \\
\text { Carica papaya } \mathrm{L}\end{array}$ & $\begin{array}{l}\text { Ekstrak daun Carica } \\
\text { papaya dapat menghambat } \\
\text { pertumbuhan sel tumor } \\
\text { secara signifikan. }\end{array}$ \\
\hline $\begin{array}{l}\text { Ahmad et } \\
\text { al }(201 \mathrm{I})\end{array}$ & $\begin{array}{l}\text { Ekstrak daun } \\
\text { Carica papaya }\end{array}$ & $\begin{array}{l}\text { Ekstrak daun Carica } \\
\text { papaya memiliki potensial } \\
\text { terhadap demam } \\
\text { berdarah. Meningkatnya } \\
\text { sel darah merah, sel darah } \\
\text { putih dan neutrophils. }\end{array}$ \\
\hline $\begin{array}{l}\text { Okeniyi } \\
\text { et al } \\
(2007)\end{array}$ & $\begin{array}{l}\text { Biji Carica } \\
\text { papaya kering }\end{array}$ & $\begin{array}{l}\text { Carica papaya efektif } \\
\text { membersihkan parasite } \\
\text { pada usus } 71.4 \% \text { dan } 100 \%\end{array}$ \\
\hline $\begin{array}{l}\text { Doughari } \\
\text { et al } \\
(2007)\end{array}$ & $\begin{array}{l}\text { Ekstrak akar } \\
\text { Carica papaya }\end{array}$ & $\begin{array}{l}\text { Ekstrak memiliki aktivitas } \\
\text { tinggi terhadap semua } \\
\text { bakteri gram negatif } \\
\text { daripada bakteri gram } \\
\text { positif. }\end{array}$ \\
\hline $\begin{array}{l}\text { Agada et } \\
\text { al }(2020)\end{array}$ & $\begin{array}{ll}\text { Biji } & \text { Carica } \\
\text { papaya } & \end{array}$ & $\begin{array}{l}\text { Ekstrak biji Carica papaya } \\
\text { dapat menghambat } \alpha- \\
\text { amilase dan } \alpha \text { enzim } \\
\text { glukosidase. }\end{array}$ \\
\hline $\begin{array}{l}\text { Rojop et } \\
\text { al }(20 \mid 2)\end{array}$ & $\begin{array}{ll}\text { Daun } & \text { Carica } \\
\text { papaya } & \end{array}$ & $\begin{array}{l}\text { Ekstrak dari Carica pepaya } \\
(0,75 \mathrm{~g} \text { dan } \mathrm{I}, 5 \mathrm{~g} / \mathrm{l} 00 \mathrm{~mL}) \\
\text { secarar signifikan } \\
\text { menurunkan } \quad \text { kadar } \\
\text { glukosa darah (p }<0,05) \\
\text { pada tikus diabetes dan } \\
\text { menurunkan kadar } \\
\text { kolesterol, triasilgliserol } \\
\begin{array}{l}\text { dan amino-transferases } \\
\text { darah. }\end{array}\end{array}$ \\
\hline $\begin{array}{l}\text { Peter et } \\
\text { al }(20 \mid 4)\end{array}$ & $\begin{array}{l}\text { Ekstrak biji dan } \\
\text { daun Carica } \\
\text { papaya }\end{array}$ & $\begin{array}{l}\text { Ekstrak air dan metanol } \\
\text { biji efektif untuk } \\
\text { menghambat bakteri } \\
\text { patogen sedangkan } \\
\text { ekstrak kloroform daun }\end{array}$ \\
\hline
\end{tabular}




\begin{tabular}{l|l|l}
\hline & $\begin{array}{l}\text { Carica papaya tidak } \\
\text { menunjukkan } \\
\text { penghambatan } \\
\text { terhadap bakteri dan } \\
\text { ekstrak daun encer } \\
\text { berpotensi untuk } \\
\text { menghambatnya. }\end{array}$
\end{tabular}

Berdasarkan dari 8 jurnal dengan 7 jurnal internasional dan I jurnal Indonesia, papaya dapat dimanfaatkan dari buah, biji, daun, dan akarnya. Udoh et al (2005) tentang aktivitas ekstrak alkaloid biji Carica papaya pada fungsi reproduksi tikus wistar jantan memdapatkan hasil dapat mencegah pembuahan dengan tidak terjadinya kehamilan setelah 3 kali pengamatan gestasi, terjadi penurunan jumlah sperma $60 \%$ dan $90 \%$ dan terjadi perubahan morfologi testis. Penelitian Otsuki et al (201I) ekstrak daun Carica papaya memiliki efek antitumor dan efek imunodilator dengan hasil berkurangnya IL-2 dan IL-4 dan peningkatan LI 2p40, ILI2p70, IFN- dan TNF. Penelitian Ahmad (20I I) ekstrak daun Carica papaya memiliki potensi untuk pengobatan demam pada demam berdarah dengan meaikkan Platelets count (PLT) dari $55 \times 10^{3} / \mu \mathrm{L}$ ke $168 \times 10^{3} / \mu \mathrm{L}$, White Blood Cells (WBC) dari $3.7 \times 10^{3} / \mu \mathrm{L}$ dan Neutrophils (NEUT) dari $46.0 \%$ ke $78.3 \%$. Penelitian Okeniti et al (2007) biji kering Carica papaya efektif membersihkan parasite pada intestinal 7I.45 dan 100\%, cacing A. lumbricoides dan $E$. histolitica efektif dibersihkan. Pada penelitian Doughari et al (2007) ekstrak akar Carica papaya memiliki aktivitas antibakteri terhadap semua bakteri gram negatif dan gram positif, gram negative lebih tinggi, dengan dengan aktivitas tertinggi (zona hambat $14 \mathrm{~mm}$ ) ditunjukkan terhadap Salmonella typhi. Penelitian Agada et al (2020) biji Carica pepaya telah menunjukkan aktivitas penghambatan yang luar biasa terhadap $\alpha$-amilase dan $\alpha$ - enzim glukosidase dan stres oksidatif dengan diabetes,merupakan mekanisme yang mungkin digunakan untuk menurunkan kadar gula darah untuk diabetes mellitus tipe 2. Namun, karakteristik ini mungkin disebabkan oleh senyawa bioaktif seperti asam oleat, asam n-heksadekanoat, asam oktadekanoat, asam I I-oktadekenoat, metil ester, dan asam pentadekanoat, 14-metil- metil ester yang mungkin bertanggung jawab atas efek yang ditimbulkan oleh ekstrak dari Carica pepaya benih dalam penelitian ini. Penelitian Rojop (20I2) tentang efek hipoglikemik dari daun Carica papaya dapat menurunkan kadar gula darah pada tikus yang diinduksi streptozocin pada dosis $(0,75, I, 5$ dan $3 g / 100 \mathrm{~mL})$ untuk tikus diabetes selama 30 hari penurunan yang signifikan pada kadar glukosa darah $(305,4 \pm 9,68 ; 306 . \pm 8,8$ dan $250 \pm 10,2$ vs 434 $\pm 7,49 \mathrm{mg} / \mathrm{dL}$, masing-masing) $(\mathrm{p}<0,00 \mathrm{l})$. Ekstrak biji Carica papaya terjadi peningkatan zona hambat $S$. aureus, P.aeruginosa dan E. coli, S. typiy, B. subtilis, Staphylococcus aureus, Streptococcus pneumonia, Bacillus cereus, Salmonella typhi, Escherichia coli dan Pseudomonas aeruginosa dengan konsentrasi $(25,75,100 \mathrm{~g} / \mathrm{ml})$ dan pelarut yang berbeda.

\section{Nanopartikel}

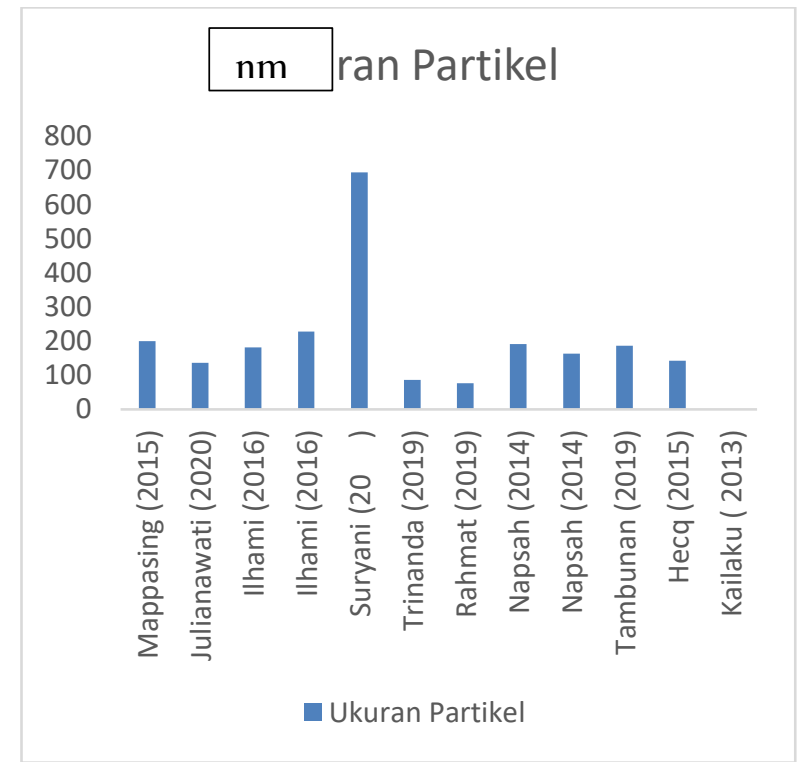

\section{Gambar I. Perbandingan ukuran partikel} nanopartikel

Hasil penelitian dari 8 atikel Internasional dan 2 artikel nasional diperoleh perbedaan ukuran partikel setiap metodenya. Penelitian dari Mappasing (2015) tentang Solid Lipid Nanopartikel, ukuran yang diperoleh, 
Shinta Nur Fajriyah,Yuliana Eka Lestari,Nadiatul Istiqamah Suaka, Endang Darmawan, 202I. Narrative Review: Nano Capsules Papaya Seed Extract (Carica Papaya L.) As Antifertility

Attama et al menyatakan., bahwa SLN yang menggunakan tween 80 bila ditambahakan fosfatidilkolin menghasilkan ukuran diameter partikel yang lebih kecil. Julianawati (2020) tentang nanopartikel ekstrak etanol daun kelor dengan menggunakan kitosan-tpp memperoleh ukuran partikel sebesar $\pm 134,78 \mathrm{~nm}$. Ilhami (2016) nanopartikel magnetik $\left(\mathrm{MnFe}_{2} \mathrm{O}_{4}\right)$ merupakan nanopartikel terbentuk dari senyawa logam, hasil penelitian ini memperoleh ukuran partikel rata rata $181.3 \mathrm{~nm}$ dan $227.3 \mathrm{~nm}$. Suryani (20 ) nanopartikel dengan teknik gelasi ionik menggunakan kitosan, tripolifosfat dan natrium alginat didapatkan ukuran partikel berkisar $693.8 \mathrm{~nm} \quad(<1000 \mathrm{~nm}$ sehingga memenuhi persyaratan ukuran nanopartikel). Triananda (2019) pembuatan nano partikel dengan metode bioreduksi diperoleh ukuran partikel rata rata $86 \mathrm{~nm}$. Rahmat (2019) pembuatan nanopartikel berbasis HPCSisteamin dilakukan dengan metode gelasi ionik dengan natrium alginate diperoleh ukuran rata rata $76.47 \mathrm{~nm}$. Napsah (2014) pembuatan nanopartikel kitosan-tpp ekstrak etanol buah mahkota dewa didapatkan ukuran partikel rata rata $190,9 \mathrm{~nm}$ dan $162,87 \mathrm{~nm}$ dengan konsentrasi yang berbeda. Tambunan (2016) tentang nanopartikel dari daun pulai memperoleh ukuran partikel rata rata $186.93 \mathrm{~nm}$. Hecq (20I5) nanopartikel dengan kitosan memperoleh ukuran partikel rata rata $142 \pm 10 \mathrm{~nm}$ dan Kailaku (2013) nanoenkapsulasi katekin memperoleh ukuran partikel rata rata $137.6 \mathrm{~nm}$.

\section{Antifertilitas}

Tabel II. Perbandingan antifertilitas dari pepaya

\begin{tabular}{l|l|lr}
\hline & $\begin{array}{c}\text { Bagian yang } \\
\text { digunakan }\end{array}$ & \multicolumn{2}{|c}{ Hasil } \\
\hline Agustine et al & Ekstrak etanol & Terjadi & penurunan \\
$(2019)$ & daun Carica & jumlah & sperma, \\
& papaya & motilitas sperma dan \\
& & pH mani & sedangkan \\
& & kematian & sperma \\
& & dan & kelainan \\
\hline
\end{tabular}

\begin{tabular}{|c|c|c|}
\hline & & $\begin{array}{l}\text { spermatozoa } \\
\text { meningkat secara } \\
\text { signifikan. }\end{array}$ \\
\hline $\begin{array}{l}\text { Rajab et al } \\
(2015)\end{array}$ & $\begin{array}{l}\text { Biji papaya ( } \\
\text { Carica papaya) }\end{array}$ & $\begin{array}{lr}\text { Kombinasi } & \text { fraksi } \\
\text { kloroform } & \text { biji } \\
\text { papaya } & \text { (Carica } \\
\text { papaya) dengan } \\
\text { fraksi methanol biji } \\
\text { saga (Abrus } \\
\begin{array}{ll}\text { precatorius) dapat } \\
\text { menurunkan }\end{array} \\
\text { spermatogenesis, } \\
\text { namun bersifat } \\
\text { reversibel }\end{array}$ \\
\hline $\begin{array}{l}\text { Udoh et al } \\
(2015)\end{array}$ & $\begin{array}{l}\text { Ekstrak biji } \\
\text { Carica papaya }\end{array}$ & $\begin{array}{l}\text { Carica pepaya } \\
\text { ekstrak mengganggu } \\
\text { aksis hipofisis gonad } \\
\text { dan memengaruhi } \\
\text { fungsi reproduksi } \\
\text { pria, yang } \\
\text { merupakan sifat } \\
\text { antifertilitasnya }\end{array}$ \\
\hline $\begin{array}{l}\text { Puspitasari } \\
(2014)\end{array}$ & $\begin{array}{l}\text { Ekstrak etanol } \\
\text { biji papaya ( } \\
\text { Carica papaya) }\end{array}$ & $\begin{array}{l}\text { Ekstrak etanol biji } \\
\text { papaya } \\
\text { meningkatkan } \\
\text { infertility, } \\
\text { menurunkan kualitas } \\
\text { telur } \\
\text { sel, mengurangi } \\
\text { jumlah folikel tersier } \\
\text { dan de Graaf di } \\
\text { ovarium dan } \\
\text { menurunkannya } \\
\text { angka pembuahan }\end{array}$ \\
\hline $\begin{array}{l}\text { Alfian et al } \\
(2018)\end{array}$ & $\begin{array}{l}\text { Ekstrak biji } \\
\text { pepaya }\end{array}$ & $\begin{array}{l}\text { Jumlah folikel de } \\
\text { Graaf ovarium } \\
\text { mencit mengalami } \\
\text { penurunan dengan } \\
\text { semakin besar dosis } \\
\text { yang diberikan maka } \\
\text { semakin sedikit } \\
\text { jumlah folikel de }\end{array}$ \\
\hline
\end{tabular}




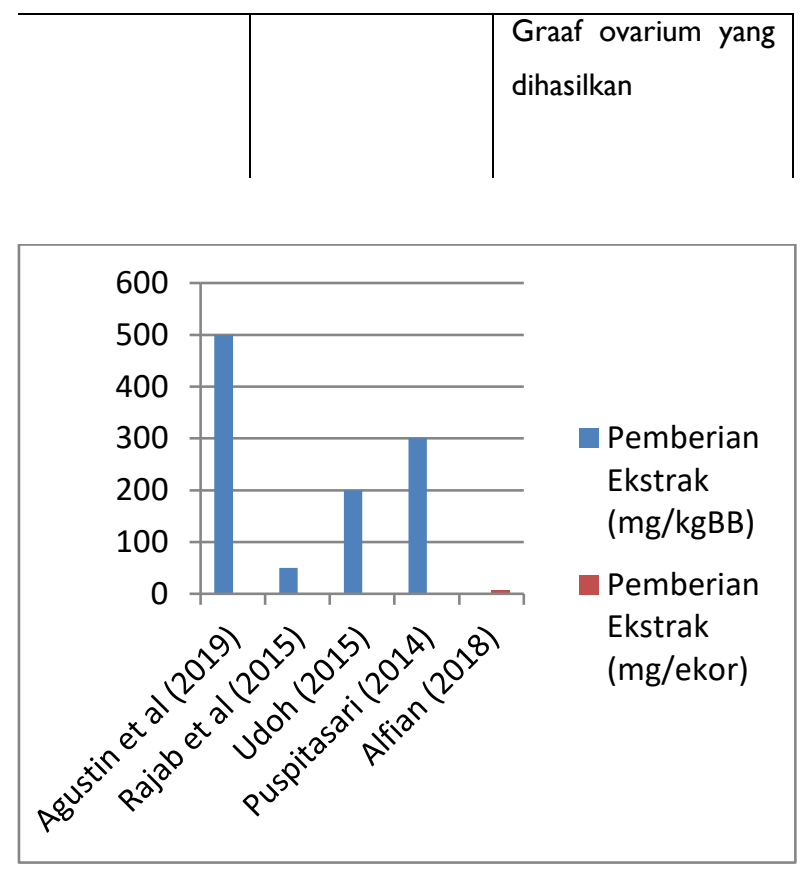

Gambar 2. Perbandingan dosis pemberian untuk antifertilitas ekstrak biji papaya

Hasil penelitian dari 3 artikel Indonesia dan 2 artikel Internasional, ekstrak daun papaya dan ekstrak biji papaya dapat digunakan sebagai antifertilitas, terdapat pada tabel II. Penelitian Agustine et al (2019) ekstrak etanolik daun Carica papaya 500mg/kgBB (gambar 2) dapat menyebabkan penurunan jumlah sperma, motilitas sperma dan $\mathrm{pH}$ air mani, selain itu mortalitas sperma dan kelainan spermatozoa meningkat secara signifikan $(p<0,05)$, kematian sperma sebesar $50 \%$ dan abnormalitas sperma $40 \%$ setelah 30 hari penelitian. Rajab et al (2015) pada penelitiannya menggunakan kombinasi kloroform biji Carica papaya dengan fraksi methanol biji saga dengan dosis 50mg/kgBB (gambar 2) hasilnya kombinasi fraksi tersebut menurunkan proses spermatogenesis bersifat reversible.

Penelitan Udoh et al (2015) efek dari ekstrak biji Carica papaya terhadap morfologi hipofisis-sumbu gonad tikus wistar jantan dengan dosis 200mg/kgBB (gambar 2) menunjukkan ahwa ekstrak carica papaya dapat menganggu aksi hipofisis gonad sehingga dapat mempengaruhi reproduksi pria yang berarti bersifat sebagai antifetilitas. Pustpitasari (2014) ekstrak etanol biji papaya sebagai antifertilitas pada tikus betina terhadap jumlah dan kualitas sel telur dengan dosis $300 \mathrm{mg} / \mathrm{kgBB}$ (gambar 2) terdapat penurunan kualitas sel telur dan tidak ada sel telur yang matang dapat mencapai tahap Metafase II. Alfian (20I8) pada penelitiannya tentang ekstrak biji papaya dengan dosis maksimal $5 \mathrm{mg} / 0.5 \mathrm{ml}$ /ekor/hari (gambar 2) dapat menurunkan jumlah folikel de Graaf ovarium pada mencit betina.

\section{PEMBAHASAN}

\section{Pepaya}

Menurut penelitian Udoh et al (2005) perlakuan tikus jantan dengan dosis ekstrak yang sesuai dapat menghambat fungsi reproduksi jantan. Hasil penelitian menunjukkan bahwa pemberian oral ekstrak biji Carica pepaya mencegah pembuahan sel telur, mengurangi jumlah sel sperma, mengungkapkan degenerasi sel sperma, dan menyebabkan lesi sel testis.

Ekstrak pepaya (I0,50, dan $150 \mathrm{mg} I \mathrm{~kg}$ hari I) pada tikus jantan menyebabkan beberapa perubahan patologis pada morfologi testis. Morfologi testis tikus jantan yang diberi ekstrak menunjukkan metaplasia sel Leydig dan Sertoli serta degenerasi spermatozoa. Efek bersih dari perlakuan ekstrak pada tikus jantan dapat mengakibatkan disfungsi reproduksi jantan. Pengamatan mikroskopis sel sperma menunjukkan bahwa pemberian ekstrak mengubah morfologi sel sperma secara patologis.

Menurut penelitian Okeniyi Otsuki et al (20II) Ekstrak daun Carica papaya dapat menghambat pertumbuhan sel tumor secara signifikan. Mungkin karena ekstrak Carica Papaya bisa menginduksi kematian sel PBMC, mirip dengan efeknya pada sel tumor. Dalam hasil percobaan, ekstrak Carica Papaya mengurangi jumlah IL-2 dan IL-4, sedangkan produksi sitokin terkait antitumor, seperti IL-I 2p40, IL-I 2p70, IFN- dan TNF-, ditingkatkan tanpa hambatan pertumbuhan. Hasil penelitian menunjukkan bahwa ekstrak Carica Papaya tidak beracun pada sel normal dibandingkan dengan pengaruhnya pada garis sel tumor. Ekstrak Carica Papaya dapat mengubah tidak 
Shinta Nur Fajriyah,Yuliana Eka Lestari,Nadiatul Istiqamah Suaka, Endang Darmawan, 2021. Narrative Review: Nano Capsules Papaya Seed Extract (Carica Papaya L.) As Antifertility

hanya aktivasi APC, tetapi juga interaksi sel T-APC atau T-B, yaitu, ekstrak Carica Papaya mengubah kekebalan bawaan dan yang didapat. Dalam penelitian, ekstrak Carica Papaya memiliki beberapa efek biologis in vitro. Hasilnya anti-proliferatif efek pada sel tumor, meningkatkan produksi sitokin tipe ThI, meningkatkan sitotoksisitas terhadap sel tumor, dan meningkatkan anti- gen terkait tumor di PBMC. Efek ekstrak Carica pepaya dapat meningkatan produksi dari sitokin tipe ThI dari limfosit manusia.

Berdasarkan penelitian yang dilakukan Ahmad et al (20II) diperoleh hasil meningkatnya sel darah merah, sel darah putih dan neutrophils. Getah, buah matang, buah mentah, biji-bijian, jus biji, akar, daun, bunga dan kulit batang Carica pepaya digunakan sebagai antimikroba, anthelmentik, antimalaria, antijamur, antiamoebic, hepatoprotektif, antifertilitas pria dan wanita, imunomodulator dan melawan histminergik. Carica pepaya mengandung dua aktif biologis penting senyawa misalnya chymopapain dan papain yang banyak digunakan untuk gangguan pencernaan. Hal ini menunjukkan papain mengandung papain, karikain, chymopapain, dan glisin endopeptidase yang dapat meningkatkan kondisi $\mathrm{pH}$ asam dan degradasi pepsin. Senyawa aktif lain dari Carica pepaya adalah lipase, atau CPL, hidrolase, yang terikat erat fraksi papain mentah yang tidak larut dalam air dan karenanya dianggap sebagai biokatalis "yang tidak dapat bergerak secara alami". Dua senyawa, I-beta-D-ribofuranosyl-3ethynyl- $[1,2,4]$ triazole (ETAR) dan I-betaDribofuranosyl4-ethynyl [I,3] imidazole (IMI8), secara signifikan mengurangi replikasi virus dengue serotipe 2 (DENV-2) di budidaya Sel Vero dan menghambat tipe Kazal trypsin noval dari Aedes aegypti memiliki aktivitas penghambatan koagulan trombin.

Hasil penelitian Okeniyi et al (2007) menunjukkan bahwa Carica papaya efektif membersihkan parasite pada usus $71.4 \%$ dan $100 \%$. Pepaya memiliki sifat antiamuba. Carica pepaya mengandung antihelmintik (Siddiqui et al., I 987 dalam Okeniyi et al., 2007), agen kimia seperti benzyl isothiocyanate dan papain (Kumar et al., 199I dan Kermanshai et al., 200I dalam Okeniyi et al., 2007). Menurut Mojica-Henshaw (2003) dalam Okeniyi et al (2007) Carica pepaya memiliki aktivitas imunomodulator lainnya. Cacing usus yang paling umum (nematoda), secara efektif dapat dibersihkan. Biji Carica pepaya dapat bermanfaat dalam pengobatan dan pencegahan parasit usus, mudah didapat, tidak berbahaya, dan murah (Okeniyi et al., 2007).

Berdasarkan penelitian Doughari et al (2007) ekstrak memiliki aktivitas tinggi terhadap semua bakteri gram negatif daripada bakteri gram positif. Senyawa bioaktif dari ekstrak akar Carica pepaya L. diekstraksi menggunakan pelarut air dan organik. Hasil penelitian menunjukkan ekstrak metanol mengandung saponin, alkaloid, tanin dan fenol, sedangkan ekstrak air panas mengandung saponin dan glikosida, sedangkan ekstrak air dingin hanya mengandung glikosida. Kehadiran zat bioaktif memberikan ketahanan tanaman terhadap bakteri, jamur dan hama dan oleh karena itu menjelaskan demonstrasi aktivitas antibakteri oleh ekstrak tanaman yang digunakan dalam penelitian ini (Srinivasan et al., 200I). Aktivitas ekstrak sebanding dengan aktivitas antibiotik.

Pada penelitian Agada et al (2020) dilakukan uji In vitro dan in vivo efek penghambatan benih Carica pepaya di $\alpha$ amilase dan $\alpha$-enzim glukosidase, diperoleh hasil Ekstrak biji Carica papaya dapat menghambat $\alpha$-amilase dan $\alpha$ enzim glukosidase. Ekstrak tumbuhan ini memiliki aplikasi terapeutik melalui saponin, flavonoid, alkaloid, terpenoid, flavonoid, steroid dan fenol (Nair et al., 2013). Ekstrak biji Carica pepaya memiliki potensi antioksidan yang luar biasa. secara in vitro, dilakukan uji antioksidan diketahui mekanisme yang digunakan ekstrak biji Carica pepaya bekerja dengan menghambat stres oksidatif yang terkait dengan diabetes tipe 2 . Temuan menunjukkan bahwa mungkin senyawa bioaktif yang ada di ekstrak biji Carica pepaya memberikan efek antidiabetik dengan menunda pencernaan karbohidrat menjadi unit yang dapat diserap. Penurunan kadar 
glukosa darah ini dapat dikaitkan dengan beberapa tingkat in vivo penghambatan melawan $\alpha$-amilase dan $\alpha$ glukosidase menghasilkan penekanan hiperglikemia (Ahmed et al., 20I5).

Hasil penelitian Rojop et al (2012) menunjukkan bahwa ekstrak air daun Carica pepaya secara signifikan menurunkan kadar glukosa darah $(p<0,05)$ pada tikus diabetes. Efek tersebut dapat terjadi karena penurunan laju penyerapan glukosa usus atau peningkatan pemanfaatan glukosa perifer. Peningkatan katabolisme glukosa terjadi karena translokasi GLUT4 ke membran plasma di otot dan sel adiposa coklat, dengan peningkatan regulasi protein-I yang tidak berpasangan di jaringan adiposa coklat dan glukoneogenesis hati, menyebabkan hiperinsulinemia atau peningkatan perifer pemanfaatan glukosa. Selain itu, hasil menunjukkan bahwa aqueous ekstrak daun Carica pepaya dapat bekerja dengan merangsang sedikit sel- $\beta$ yang tersisa dengan pelepasan lebih banyak insulin, bukan mengarah ke regenerasi sel-sel- $\beta$ yang bertanggung jawab atas peningkatan insulin. Kerusakan pulau pada tikus diabetes diobati dengan ekstrak Carica pepaya berkurang. Sel- $\beta$ menunjukkan potensi luar biasa untuk regenerasi pada tahap praklinis diabetes yang merupakan kunci saat menangani diabetes tipe I. Maka, efek antidiabetes dari ekstrak Carica pepaya dapat disebabkan oleh kandungan konstituen kimiawi yang bertanggung jawab atas tindakan antioksidan. Pemberian ekstrak daun Carica pepaya menginduksi penurunan yang signifikan dalam konsentrasi plasma glukosa dan triasilgliserol (0,75 dan I,5 g / $100 \mathrm{~mL})$. Selain itu, ekstrak ini menunjukkan aksi antioksidan dan tidak hepatotoksik pada dosis rendah (0,75 dan I,5 g/ 100 $\mathrm{mL}$ ). Mekanisme untuk Carica pepaya mirip dengan beberapa sterol yang menurunkan aktivitas enzim penghidrolisis lipid dan karbohidrat di usus kecil, sehingga mengurangi konversi disakarida dan trigliserida menjadi monosakarida yang dapat diserap dan asam lemak bebas.
Menurut penelitian Peter et al (2014) terungkap bahwa ekstrak air dan metanol biji Carica papaya efektif untuk menghambat bakteri patogen sedangkan ekstrak kloroform daun Carica papaya tidak menunjukkan penghambatan terhadap bakteri dan ekstrak daun encer berpotensi untuk menghambatnya. Ekstrak encer, nheksana dan etanol dari Daun Carica pepaya diteliti oleh Chandra et al., 20I I untuk aktivitas antibakteri S. aureus, B. subtilis, E. coli, dan Pseudomonas auruginosa, diperoleh bahwa ketiga ekstrak tersebut mampu menghambat semua bakteri yang diuji. Ekstrak menunjukkan aktivitas yang lebih tinggi terhadap semua bakteri Gram negatif daripada bakteri Gram positif yang diuji, dengan aktivitas tertinggi (zona penghambatan $16 \mathrm{~mm}$ ) ditunjukkan terhadap Salmonella typhi. Ogunjobi dan Ogunjobi (20II) menyatakan ekstrak etanol daun dan akar cukup untuk membunuh semua bakteri patogen dibandingkan ekstrak air daun dan akar. Hema et el (2013) menunjukkan bahwa ekstrak propanolic Carica pepaya lebih efektif daripada ekstrak etanol yang menunjukkan aktivitas tertinggi. Di antara bakteri Gram positif dan Gram-negatif yang diuji terhadap ekstrak daun Carica pepaya, bakteri Gram-negatif lebih rentan khususnya Proteus vulgaris untuk ekstrak. Hasil ini, berbeda dengan laporan sebelumnya yang menunjukkan bahwa ekstrak tumbuhan lebih aktif melawan bakteri Gram-positif daripada Gram-negatif. Romasi et al (20I I) menyatakan bahwa ekstrak daun pepaya dapat, menghambat pertumbuhan Rhizopus stolonifer.

\section{Nanokapsul}

Menurut penelitian Mappasing et al (20I5), kombinasi surfaktan lebih efektif bekerja menstabilkan SLN bila dibandingkan penggunaan surfaktan tunggal. Oleh karena itu, pada penelitian ini ditambahkan kombinasi dua surfaktan yaitu fosfatidilkolin dan tween 80 kedalam formula SLN. Resveratrol didispersikan didalam fase lemak GMS membentuk emulsi air dalam minyak $(\mathrm{a} / \mathrm{m})$, kemudian ditambahkan tween 80 untuk membentuk emulsi a/m/a dengan globul yang lebih kecil. Semakin besar jumlah lemak dalam formula SLN, ukuran dan 
Shinta Nur Fajriyah,Yuliana Eka Lestari,Nadiatul Istiqamah Suaka, Endang Darmawan, 2021. Narrative Review: Nano Capsules Papaya Seed Extract (Carica Papaya L.) As Antifertility

indeks polidispersitasnya semakin besar. Demikian pula penelitian yang dilakukan oleh Shah et al., diperoleh adanya peningkatan ukuran diameter partikel dan peningkatan indeks polidispersitas seiring dengan peningkatan jumlah GMS dengan jumlah surfaktan yang konstan.

Dari hasil pengukuran diameter partikel SLN dan indeks polidispersitasnya, diketahui bahwa semakin besar jumlah GMS dalam formula SLN, maka diameter partikel dan indeks polidispersitasnya cenderung membesar. Hal ini dikarenakan bertambahnya komposisi lemak dan jumlah surfaktan yang tetap akan membentuk ukuran partikel yang lebih besar, karena luas permukaan yang dapat tertutupi oleh surfaktan tidak meningkat. Sementara itu, jumlah lemak yang bertambah mengakibatkan adanya permukaan lemak yang tidak dapat tertutupi oleh surfaktan sehingga lemak akan beraglomerasi dan menghasilkan ukuran partikel yang lebih besar. SLN resveratrol yang diperoleh dari penelitian ini memiliki ukuran $334,4 \mathrm{~nm}$. Dengan ukuran tersebut, lapisan oklusif dapat terbentuk setelah diaplikasikan pada kulit.

Berdasarkan penelitian dari Julianawati (2020) tentang nanopartikel ekstrak etanol daun kelor dengan menggunakan kitosan-tpp diperoleh ukuran partikel sebesar $\pm 134,78 \mathrm{~nm}$. Pada penelitian ini menggunakan metode gelasi ionik. Metode gelasi ionik merupakan metode yang mudah dibandingkan dengan metode yang lainnya.

Mekanisme terbentuknya nanopartikel dengan bahan kitosan dengan cara adanya interaksi elektostatic antara gugus amina dan gugus negatif dari polianion seperti tripolifosfat. Pengadukan kitosan yang larut dalam asam asetat dan penambahan anionik polimer dengan macnetic strirrer bertujuan untuk memecah partikelpartikel agar mendapatkan ukuran nano. Pada ukuran partikel nanopartikel ekstrak daun kelor didapatkan ukuran yang baik dalam sistem penghantar obat karena ukuran tersebut < 300nm. Bentuk ukuran partikel banyak dipengaruhi oleh beberapa faktor diantaranya konsentrasi TPP, konsentrasi larutan kitosan, rasio volume larutan kitosan dan TPP, lama pengadukan, kecepatan pengadukan, dan lamanya waktu penyimpanan.

Uji partikel dengan PSA cenderung menghasilkan ukuran lebih besar dibandingkan dengan metode lain. Hal ini terjadi karena adanya agregasi dan swelling dari partikel kitosan. Agregasi dapat terjadi seiring dengan meningkatnya nilai $\mathrm{pH}$ karena gugus positif $\mathrm{NH}^{3+}$ dari kitosan terikat dengan gugus $\mathrm{OH}$ menarik $\mathrm{H}^{+}$berlebih dari $\mathrm{NH}^{3+}$ membentuk $\mathrm{NH}_{2}$ Kehilangan muatan partikel mengakibatkan antar partikel bertumbuhan mengalami agregasi. Sedangkan swelling terjadi akibat adanya penolakan elektrostatis antar gugus ion yang memiliki muatan. Meningkatnya $\mathrm{pH}$ membuat kelarutan kitosan menurun sehingga ukuran partikel meningkat. Swelling menyebabkan ukuran partikel membesar akibat penyerapan air. Oleh karena itu, penambahan NaTPP pada pembuatan nanopartikel ekstrak daun kelor bertujuan untuk meningkatkan biokompabilitas dan menurunkan derajat swelling pada kitosan.

Hasil penelitian Ilhami (2016) pada nanopartikel magnetik (MnFe2O4) berlapis HSA, diperoleh ukuran partikel rata rata $181.3 \mathrm{~nm}$ dan $227.3 \mathrm{~nm}$. Menurut Fahmi (2014) dalam Ilhami (2016) dijelaskan, semakin besar konsentrasi BSA yang digunakan dalam pencampuran, maka nanopartikel yang terbentuk akan semakin kecil.

Berdasarkan penelitian Suryani (2014) tentang formulasi nanopartikel kurkumin dengan teknik gelasi ionik menggunakan kitosan, tripolifosfat dan natrium alginat diperoleh ukuran partikel berkisar 693.8 nm. Hasil pengamatan menunjukkan bahwa semakin tinggi konsentrasi kitosan dan TPP, maka semakin banyak endapan yang terbentuk. Hal ini mungkin disebabkan karena pada konsentrasi kitosan yang tinggi, partikelpartikel yang terbentuk dari interaksi ionik antara kitosan dan TPP sangat banyak dan padat sehingga bergerombol membentuk agregat menjadi partikel berukuran besar. Peningkatan jumlah TPP maka 
kelebihan TPP akan menghasilkan interaksi ionik antar nanopartikel sehingga membentuk nanopartikel berukuran besar. Peningkatan konsentrasi natrium alginat juga menunjukkan peningkatan jumlah endapan. Hal ini sesuai dengan hasil penelitian yang dilakukan oleh You et al (2006), bahwa nanopartikel yang mengandung kitosan dan natrium alginat akan saling berinteraksi melalui gerak Brown untuk membentuk gumpalan.

Menurut penelitian Trinanda (2019) proses pembuatan NPP (nanopartikel-perak) dengan metode bioreduksi telah terbentuk jika terjadi perubahan warna pada larutan dari hijau menjadi kuning hingga kecoklatan, dimana larutan $\mathrm{AgNO}_{3}$ yang berwarna bening berubah menjadi warna coklat, yang terjadi dikarenakan tereduksinya ion $\mathrm{Ag}^{+}$menjadi $\mathrm{Ag}^{0}$. Gugus fungsi dari senyawa metabolit sekunder daun Ipomoea batatas $\mathrm{L}$. mendonorkan elektron ke ion $\mathrm{Ag}^{+}$dan mereduksinya menjadi $\mathrm{Ag}^{0}$. Adanya gugus $-\mathrm{OH}$ pada suatu senyawa fenolik jika direaksikan dengan $\mathrm{AgNO}^{3}$ akan memungkinkan terjadinya ikatan rangkap terkonjugasi yang menyebabkan terjadinya perubahan warna larutan. Pada awalnya gugus hidroksil $\left({ }^{-} \mathrm{OH}\right)$ akan berubah menjadi karboksil $(=0)$ setelah bereaksi dengan $\mathrm{AgNO}^{3}$ dan akibat karena sifat keelektronegatifan yang dimiliki $\mathrm{O}$ akan mengalami gaya tarik-menarik dengan atom $\mathrm{Ag}^{0}$ yang memiliki ukuran yang sangat kecil serta masih memiliki proton dan elektron yang terus bergerak (dislokasi), sehingga proton bermuatan + yang ada akan lebih tertarik kearah atom $\bigcirc$ yang bersifat elektronegatif.

Berdasarkan penelitian Rahmat (2019) pembuatan nanopartikel berbasis HPC-Sisteamin dilakukan dengan metode gelasi ionik dengan natrium alginat sebagai penggelasi, metode gelasi ionik digunakan karena polimer yang digunakan merupakan polimer kationik, sehingga dapat disilangkan menggunakan crosslinker bermuatan negative, selain itu proses yang digunakan sederhana. Polimer HPC dimodifikasi menjadi tiomer HPC-sisteamin dengan menambahkan ligan sisteamin untuk menambahkan gugus sulfhidril pada polimer HPC dengan reaksi reduksi aminasi. Pembuatan nanopartikel dilakukan dengan cara menambahkan crosslinker yang memiliki polianion seperti natrium tripolifosfat (NaTPP) dengan polianion tripolifosfat, natrium alginat dengan polianion karboksilat dan dapar fosfat dengan anion fosfat kedalam larutan tiomer HPC-sisteamin. Hasil uji pemeriksaan ukuran partikel dengan crosslinker natrium alginat memiliki ukuran partikel $76,47 \mathrm{~nm}$ dengan indeks polidispersitas 0,35I. Sedangkan dengan crosslinker dapat fosfat memiliki ukuran partikel sebesar 48,56 nm dengan pdl 0,402.

Menurut penelitian Napsah (2014) mekanisme terbentuknya formulasi nanopartikel kitosan-TPP dengan metode gelasi ionik ini berdasarkan pada interaksi elektrostatik antara gugus amina kitosan dengan gugus muatan negatif dari suatu polianion (Tiyaboonchai et al., 2003). Gugus amina pada kitosan yang dilarutkan dalam dapar $\mathrm{pH} 4$ akan terprotonasi membentuk amina+kationik (-NH ). TPP mempunyai muatan 3 negatif sehingga dapat berfungsi sebagai polianion. Reaksi dengan komponen bermuatan negatif baik ion ataupun molekul dapat menyebabkan pembentukan jaringan antara rantai polimer melalui jembatan ionik (Kumar, 2006). Pada penelitian ini, hasil pengukura formula $P$ dan $R$, diperoleh rata-rata 190,9 dan 162,87 nm. Penggunaan kitosan yang berlebih menyebabkan ukuran partikel semakin besar, seperti terjadi pada formula $\mathrm{P}$, jumlah ekstrak yang digunakan lebih sedikit dibanding dengan kitosan sehingga zat aktif yang bereaksi dengan kitosan sedikit, sehingga sisa kitosan yang tidak bereaksi akan mengikat kembali zat aktif sehingga menyebabkan ukuran partikel semakin besar.

Berdasarkan penelitian Tambunan (2019), hasil uji pemeriksaan ukuran partikel pada larutan nanopartikel ekstrak daun pulai menunjukkan ukuran partikel yang memenuhi syarat ukuran nanopartikel yaitu $186,93 \mathrm{~nm}$. Semakin besar kekuatan tolak menolak antara partikel maka semakin kecil kemungkinan partikel bergabung dan membentuk agregat. Efek ini berhubungan dengan 
pengikatan gugus anionik oleh gugus amin yang panjang dari kitosan untuk menjada nilai elektrik yang tinggi sehingga dapat mencegah terjadinya agregasi.

Hasil penelitian Hecq (2015) menunjukkan bawa kitosan dan turunan kitosan terbukti berperan sebagai peningkat permeasi. Nanopartikel yang diselidiki dibentuk berdasarkan interaksi cepat antara kitosan atau HTCC (yang bertanda positif) dan polianion seperti TPP dan insulin (yang dibebankan secara negatif pada kondisi tertentu). Hasil yang disajikan menunjukkan bahwa penggunaan turunan kitosan seperti HTCC bersama dengan TPP memungkinkan untuk mempertahankan pelepasan insulin yang dienkapsulasi. Penambahan TPP mempengaruhi baik pelarutan matriks serta pelepasan obat dari nanopartikel.

Berdasarkan penelitian Kailaku (20/3) diperoleh nanoenkapsulasi katekin dengan kitosan sebagai bahan enkapsulasi dengan formula terbaik yaitu dengan ukuran partikel $137.6 \mathrm{~nm}$.

Hasil analisis ukuran partikel menunjukkan bahwa ukuran partikel sangat dipengaruhi oleh konsentrasi konsentrasi pelarutan kitosan. Produk dengan konsentrasi larutan kitosan 0,2\% memiliki ukuran partikel yang lebih kecil dibandingkan dengan produk dengan konsentrasi larutan kitosan 0,4\%. Semakin tinggi konsentrasi Na-TPP (0,2\%) dengan konsentrasi kitosan 0,2\% menghasilkan ukuran partikel katekin nanoenkapsulasi yang lebih kecil dibandingkan dengan konsentrasi Na-TPP 0, I\%. Namun pada produk dengan konsentrasi kitosan 0,4\%, semakin tinggi konsentrasi Na-TPP menghasilkan ukuran partikel yang semakin besar, hal ini sejalan dengan temuan (Dhudani et al., 2010). Peningkatan konsentrasi padatan terlarut dan konsentrasi kitosan dan Na-TPP menghasilkan aglomerasi dan ukuran partikel yang lebih besar.

\section{Antifertilitas}

Berdasarkan pada tabel II terdapat perbedaan mekanisme antifertilitas dari ekstrak daun dan biji Carica papaya. Pada penelitian Agustine et al (2019) antifertilitas ditargetkan untuk tikus jantan sehingga dapat menurunkan jumlah sperma motalitas sperma dan $\mathrm{pH}$ mani sedangkan kematian sperma dan kelainan spermatozoa meningkat secara signifikan. Pada penelitan Rajab et al (20I5) antifertilitas terhadap spermatogenesis pada tikus jantan dengan parameter menurunkan proses spermatogenesis tetapi bersifat reversible. Penelitian Udoh et al (20I5) antifertilitasnya pada morfologi hipofisis gonad tikus jantan dengan parameter dapat menganggu aksi hipofisis gonad tikus jantan. Penelitian Puspitasari (2014) antifertilitasnya terhadap jumlah dan kualitas sel telur pada tikus betina dengan parameter penurunan jumlah dan kualitas sel telur. Alfian (20I8) antifertilitasnya terhadap jumlah folikel de Graaf pada mencit betina. Antifertilitas dari tumbuhan obat dapat bekerja dengan 2 cara yaitu dengan melalui efek sititoksik dan efek hormonal yang dapat menganggu keseimbangan hormonal.

Perbedaan mekanisme target tersebut berdasarkan senyawa aktif dari bagian yang diambil untuk penelitian, perbandingan dosis pemberian, dan cara pembuatan ekstrak.

Penelitian Agustine et al (2019) menggunakan bagian daun atau dari ekstrak daun Carica papaya. Daun Carica pepaya telah terbukti mengandung banyak komponen aktif seperti papain,hymopapain, cystatin, à-tocopherol, asam askorbat, flavonoid cyanogenicglucosides dan glukosinolat yang dapat meningkatkan daya antioksidan total dalam darah dan menurunkan tingkat peroksidasi lipid (Seigler dkk.,2002). Daun ekstrak Carica papaya memiliki kemampuan untuk menurunkan aktivasi dari ATP yang dapat menekan laju motilitas sperma karena ATP merupakan sumber energi utama sperma sehingga ekstrak biji papaya dapat menghambat motilitas sperma pada tikus. Sedangkan pada kelainan sperma pada hewan disebabkan karena kerusakan sel sertoli yang berperan penting dalam menjaga lingkungan yang kondusif untuk spermatogenesis, akibat dari kerusakan sel sertoli maka menyebabkan peningkatan abnormalitas sperma. Selain itu ekstrak daun Carica papaya dapat menyebabkan 
penurunan $\mathrm{pH}$ yang menyebabkan media plasma mani menjadi asam sehingga membuat sperma sangat rapuh sehingga dapat menyebabkan kematian.

Sedangkan pada penelitian Rajab et al (20I5), Udoh et al (2015), Puspitasari (2014), dan Alfian (2018) antifertilitas dari bagian biji Carica Papaya. Senyawa yang terkandung dalam biji pepaya seperti golongan saponin, tanin, flavonoid, terpenoid, alkaloid, sterol serta triterpene dapat menekan tingkat fertilitas dengan cara mengganggu fungsi ovarium, uterus atau vagina (Setyowati et al., 20I5). Rajab et al (2015) ekstrak biji Carica papaya bekerja secara hormonal yaitu dengan menghambat pengeluaran hormon reproduksi yang mengakibatkan proses spermatogenesis terhambat diduga karena adanya senyawa alkaloid, apabila hormon FSH menurun maka tidak dapat merangsang sel sertoli yang mengakibatkan terganggunya sel sertoli dan terjadi penurunan spermatogenesis. Udoh et al (2015) Carica papaya dapat merangsang produksi folikel hormon FSH berlebihan dan hormon LH yang dapat menyebabkan penekanan sel sertoli sehingga menghambat spermatogenesis. Puspitasari (20l4) bahan aktif saponin dapat menganggu jalur hipotalamus hipofise yang menganggu sekresi $\mathrm{GnRH}$ sehingga berpengaruh pada pembentukan, perkembangan dan pematangan folikel. Saponin dapat menekan perkembangan sel granula yang mengatur hormon perangsang folikel dalam ovarium sehingga dapat sebagai antifertilitas. Alfian (2018) senyawa senyawa yang terkandung dalam biji papaya menganggu sekresi FSH dan LH sehingga dapat menganggu proses folikulogenesis.

Dosis pemberian juga mempengaruhi dalam keberhasilan antifertilitas. Dosis atau konsentrasi ekstrak tercantum pada gambar 2. Pada penelitan Agustine et al (2019) dosis yang dihunakan sebesar $500 \mathrm{mg} / \mathrm{kgBB}$, Rajab et al (2015) sebesar $50 \mathrm{mg} / \mathrm{kgBB}$, Udoh et al (2015) dosis sebesar 200mg/kgBB, Puspitasari (2014) dosis sebesar 300mg/kgBB dan Alfian (2018) $7 \mathrm{mg} / 0,5 \mathrm{ml} /$ ekor/hari. Perbedaan dosis tersebut berdasarkan dosil hasil konversi terhadap hewan uji, ataupun konsentrasi dari masing masing eksktrak.

Selain itu dipengaruhi dari sediaan ekstrak yang dibuat. Dari kelima jurnal ekstrak diperoleh dari pencucian, pengeringan daun/biji, lalu dilakukan penggilingan dan di ekstraksi dengan pelarut yang sesuai.

\section{KESIMPULAN}

Secara keseluruhan dapat disimpulkan bahwa I) Dosis optimum sebagai antifertilitas dari ekstrak biji Carica papaya adalah $5 \mathrm{mg} / 0,5 \mathrm{ml} / \mathrm{ekor} / \mathrm{hari}$, jumlah folikel de Graaf ovarium mencit mengalami penurunan dengan $\bar{x}$

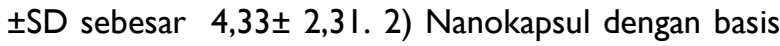
HPC-Sisteamin memiliki ukuran partikel terkecil 76,47 $\mathrm{nm}$ sedangkan nanokapsul dengan basis kitosan-NaTPP memiliki ukuran partikel terkecil $86,0 \mathrm{~nm}$, nanopartikel atau nanokapsul dengan polimer digunakan untuk meningkatkan bioavailabilitas, pelepasan obat terkendali atau melarutkan obat untuk penghantaran sistemik. 3) Ekstrak biji Carica papaya berguna sebagai antifertilitas dengan mekanisme menurunkan proses spermatogenesis, menganggu hipofisis gonad dan mempengaruhi fungsi reproduksi, menurunkan kualitas telur dan meningkatkan infertility, dan menurunkan jumlah folikel de Graaf.

\section{UCAPAN TERIMA KASIH}

Berisi Informasi ucapan terima kasih serta penghargaan kepada pihak-pihak yang telah berpartisipasi dalam kegiatan penelitian yang dilakukan. Bisa kepada institusi penyedia anggaran maupun hibah (mencantumkan sumber dan skema hibah yang digunakan), pihak institusi tempat kegiatan penelitian dilakukan, narasumber, organisasi dan unsur masyarakat, serta sivitas akademika yang telah membantu pelaksanaan kegiatan penelitian. 


\section{REFERENSI}

I. Fauziya, S., \& Krishnamurthy, R. (20/3). Papaya (Carica papaya): Source material for anticancer. CIBTech Journal of Pharmaceutical Sciences, 2(I), 2534.

2. Pavithra, C. S., Devi, S. S., Suneetha, W. J., \& Rani, C. V. D. (2017). Nutritional properties of papaya peel. The Pharma Innovation Journal, 6(7), 170-173.

3. Peter, J. K., Kumar, Y., Pandey, P., \& Masih, H. (2014). Antibacterial activity of seed and leaf extract of Carica Papaya var. Pusa dwarf Linn. IOSR Journal of Pharmacy and Biological sciences, 9(2), 2937.

4. Charan, J., Saxena, D., Goyal, J. P., \& Yasobant, S. (2016). Efficacy and safety of Carica papaya leaf extract in the dengue: $A$ systematic review and meta-analysis. International Journal of Applied and Basic Medical Research, 6(4), 249-254.

5. Satriyasa, B. K., Mahendra, A. N., Arijana, I. G. K., \& Ruspawan, D. M. (20I8). Unripe Papaya Seed Ethanol Extract (Carica Papaya, Linn.) Inhibits FSH and LH of Male Mice (Mus Musculus). Biomedical and Pharmacology Journal, I I (2), 979-984.

6. Rachmawati, A. L., \& Surini, S. (20/8). Formulasi dan Karakterisasi Nanopartikel Sambungsilang Gom Xantan dan Gom Akasia Untuk Penghantaran Insulin Oral. Pharmaceutical Sciences and Research (PSR), 5(3), 159-168.

7. Julianawati, T., Hendarto, H., \& Widjiati. (2020). Penetapan Total Flavonoid, Aktivitas Antioksidan dan Karakterisasi Nanopartikel Ekstrak Etanol Daun Kelor (Moringa pterygosperma Gaertn.). Jurnal Penelitian Kesehatan" SUARA FORIKES"(Journal of Health Research" Forikes Voice"), I I(I), 49-54.

8. Martien, R., Adhyatmika, Irianto, I. D. K., Farida, V., \& Sari, D. P. (2012). Perkembangan Teknologi Nanopartikel Sebagai Sistem Penghantaran Obat. Majalah Farmaseutik, 8(I), 133-144.

9. Dai, T., Tanaka, M., Huang, Y. Y., \& Hamblin, M. R. (20II). Chitosan preparations for wounds and burns: antimicrobial and wound-healing effects. Expert review of anti-infective therapy, 9(7), 857879.

10. Li, J., Cai, C., Li, J., Li, J., Li, J., Sun, T., Wang, L., Wu, H., \& Yu, G. (2018). Chitosan-based nanomaterials for drug delivery. Molecules, 23(10), 2661.
II. Gan, Q., Wang, T., Cochrane, C., \& McCarron, P. (2005). Modulation of surface charge particle size and morphological properties of chitosan-TPP nanoparticles intended for gene delivery. Colloids and Surfaces B: Biointerfaces, 44(2-3), 65-73.

12. Sreekumar, S., Goycoolea, F. M., Moerschbacher, B. M., \& Rivera-Rodriguez, G. R. (20/8). Parameters influencing the size of chitosan-TPP nano-and microparticles. Scientific reports, 8, I-II.

13. Agada, R., Usman, W. A., Shehu, S., \& Thagariki, D. (2020). In vitro and in vivo inhibitory effects of Carica papaya seed on $\alpha$-amylase and $\alpha$-glucosidase enzymes. Heliyon, 6(3).

14. Mappamasing, F., Anwar, E., \& Mun'im, A. (2015). Formulasi, Karakterisasi dan Uji Penetrasi In Vitro Resveratrol Solid Lipid Nanopartikel dalam Krim Topikal. Jurnal Ilmu Kefarmasian Indonesia, I3(2), 137-144.

15. Ilhami, F. B. (2016). Efektifitas Nanopartikel Magnetik (MnFe2O4) Berlapis HSA Tertarget Reseptor Folat Terhadap Sel Kanker. Jurnal Biosains Pascasarjana, 18(2), I40-152.

16. Suryani., Musnina, W. O. S., \& Anto, A. S. (2017). Optimasi Formula Matriks Patch Transdermal Nanopartikel Teofilin dengan Menggunakan Metode Simplex Lattice Design (SLD). Pharmauho: Jurnal Farmasi, Sains, dan Kesehatan, 3(I), 26-32.

17. Trinanda, R., Sundaryono, A., \& Handayani, D. (2019). PEMBUATAN NANOPARTIKEL-PERAK EKSTRAK DAUN UBI JALAR ORANGE (IPomoea batatas L.) DENGAN METODE BIOREDUKSI DAN UJ AKTIVITAS TERHADAP JUMLAH TROMBOSIT Mus musculus. Alotrop, Jurnal Pendidikan Dan Ilmu Kimia, 3(I), 76-8I.

18. Hecq, J., Siepmann, F., Siepmann, J., Amighi, K., \& Goole, J. (2015). Development and evaluation of chitosan and chitosan derivative nanoparticles containing insulin for oral administration. Drug development and industrial pharmacy, 4 I(I2), 20372044.

19. Kailaku, S. I., Mulyawanti, I., \& Alamsyah, A. N. (2014). Formulation of nanoencapsulated catechin with chitosan as encapsulation material. Procedia chemistry, 9, 235-24I.

20. Alfian, M. A. J., Sitasiwi, A. J., \& Djaelani, M. A. (2018). Efek antifertilitas ekstrak air biji pepaya (carica papaya l.) terhadap jumlah dan diameter folikel de graaf mencit (mus musculus) betina. ProLife, 5(I), 476-486. 
21. Rachmawati, H., Reker-Smit, C., Hooge, M.N.L., Loenen-Weemaes, A.M.V., Poelstra, K., Beljaars, L. 2007. Chemical Modification of Interleukin-10 with Mannose 6-Phosphate Groups Yield a Liver-Selective Cytokine. DMD, 35, 8|4-82I.

22. Rahmat, D., \& Salim, S. (20/9). Uji Mukoadhesif Nanopartikel Crude Bromelin dari Perasan

Bonggol Nanas Berbasis Hidroksi Propil SelulosaSisteamin. Majalah Farmasetika, 4, I I3-I I8. 